\title{
INTEGRATION OF DISABLED PEOPLE IN LITHUANIA- PROBLEMS AND PERSPECTIVES FROM THE EDUCATION POINT OF VIEW
}

\author{
Rita Virbaliene \\ M. Romeris university, Educology institute, Lithuania
}

\begin{abstract}
The article analyses the dynamics of the integration of childrenwith special educational needs to Lithuanian general educational institutions by year 2003-2012. Special education is often realized only like a formal transfer of childrenwith special educational needs from one institution to another, without giving sufficientlyqualified help. General educational institutions aren't always ready to educate disabled child, because not always a physical environment, educational andcompensatory remedies are adapted. Are teachers ready to receive children with special educational needs, are teaching assistants contained in schools?
\end{abstract}

Key words:special educational needs, special education, integration.

\section{Introduction}

The integration of children with special needsis a pressing problemin Lithuania, as in all Europe. When Lithuania became an independent state and the principle of equal opportunities was admited, came up premises for person with limited availability to organize his life in the same principles like all other people. For a human, for an individual - it's impossible to exist alone. The essentialpremise for the full-fledged existence - community life(Vanier, 1998), that's why in all stages of human development, one of the most relevant questions was the place of the individual in society, how important is his role, interpersonal relationships. According to J. Ruškus and G. Gedviliene (1997), the opportunity to live full-fledged life for disabled person is determined by the two-way interaction: preparation to admit a different person by members of the society and preparation to be active by person with limited availability. These two conditions, which can ensure the full-rate reciprocity, arent ${ }^{6} t$ able to come by itself. It's necessary cognitive and confidant atmosphere, which forms when people communicate and act together.

The dynamics and inclusion forms of the integration of children with special educational needs to general educational institutions are analysed in the article. In literature, the definition of integration is the process of change, stimulating $a$ new look at all educational process. In the democratic society, the integration is realised as natural and irreversiblephenomenon. The integration often reaps various opinions and assessments,special education is often realized only like a formal transfer of children with special educational needs from one institution to another, without giving qualified assistance. The system of special education in Lithuania, like in any other country, is specific and determined by particular 
factors of history and culture, because different countries have a different experience in this field. The society's view to the children with special educational needs is being formed by country's traditions, philosophical attitudes, education and training policy. When country's education policy is being formed, it's very important to not forget to form a positive attitude about integration of disabled people and hold it by giving the same conditions of education to every child, considering to his capacities and abilities. In education is very important to trust yourself and others, being tolerant of each other. Special education is grounded by principles of general and special pedagogy.

The aim of the article - to analyse and describe theoretical background for inclusion of children with special educational needs to Lithuanian general educational system. Goals:

1) to display and describe basic forms of special education.

2) to analyse problems of the integration of children with special educational needs to Lithuanian general education schools.

3) to evaluate perspectives of special education in Lithuania.

Methods: scientific literature, statistics and rule of law analysis.

\section{Integrated education in school of general education}

The democratic consciousness of the people and lifestyle depend on the educational system and its content of the country. On purpose to make premises for personal social and cultural development, successful cultural, social and economic development of Lithuanian society in rapidly changing living conditions and educational system. It strains after to develop the attitudes and abilities:

- to think logically and constructively, to choose reasonably, to decide wisely;

- lifelong learning,constantly expanding common cultural, social and professional competence;

- to harmoniously socialize and collaborate with people from different societies and cultures;

- to be competent and responsible in all spheres of life.

The point of integration is that a disabled person is able to participate in a community of healthy people. In Lithuanian educational terminology are used two conceptions for integrated education levels - a partial integration and a full integration (LR Special Education Law,1998).

Daniel P.Hallahan, James M. Kauffman in their book „Exceptional Children: introduction to special education“" (2003) prescribe 8 strategies of organizing integrated learning:

1. Work of specialists teams(ST). These are teams, which contain specialists of various fields, usually general and special education pedagogues, in 
collaboration with teachers of general classes for educational strategies for children with a learning disability.

2. Peer cooperation. It is a process, when two pedagogues generate ideas about working with a children with a learning disability by dialoge.

3. Peer counseling. In this case, a special pedagogue works with general education pedagogue by creating educational strategies for disabled pupils.

4. Collective teaching. In this way, general and special education pedagogues have sessions together, in single classes; this way helps special educator to survey the atmosphere of collective classes.

5. Collaborative learning. It is a learning way, when teacher gives the common tasks for children with various disabilities.

6. Peer mentoring. The method is based on point of view that students are successfully able to teach each other. Specialists advise to allow disabled children to be tutors, not only students.

7. Limited participation in a particular activity. A teacher applies a specific child-appropriate activity that he could get involved as much as possible.

8. Programs to change attitudes. The movement of these programs is committed to introduce children with aspects of various disabilities.

According to I. Elijošienè (1998), the integrated education shouldn't be understood like a physical transfer of a child from special to general education school, without special help. It is necessary to integrate children only when we are sure that all conditions for successful integration are created. However, the development of successful integration is impeded by how teachers and students react to children with special educational needs in their classes. The most common reactions are exaggerated problem of a child fixation, orientation on what a child can't do, what he isn't able to do, so-called labeling: marplot, unapt, bugger, scatterbrain or just rejection, teachers arguments: „I have not special preparation“, „I can“t work with these children“, „too much students in my class".

However, such teachers attitude about children with special educational needs can be explained by the fear not to come up to parents and children expectations of sufficient understanding of child's problem, that general education schools aren't provided enough to content individual needs of childrens (alternative teaching tools, programs, tasks, and so on.). Pedagogues have professional competence, are able to individualize educational programs, apply new teaching methods, but there's lack of special pedagogues, assistants, which could help children during lessons in educational institutions. The pressing problem parent - teacher partnership. Is noticed, that parents are quite active participants. The most important task for a teacher who has children with special needs in his class - to access a child, to admit him. Both teacher and child should feel simplicity of intercommunion, closeinterconnection. On pedagogue depends not only his and child's interaction, but the attitude of other children to disabled 
child. Teacher's created atmosphere, substantiated and unsubstantiated influence form close reciprocal understanding, respect, assistance or a climate of hostility in class. Teacher is like creator. The education is extremely complicated, various and multi-stage process. Educational participants interaction's situations, cases of exposures are unlimited, that's why it is impossible to formulate advices for all educational problems, ready-made formulas for every case of educational process can't be found and adapted (Stulpinas, 1993).

Negative teachers reactions to integrated child, low educational achievements, what makes these children not able to compete with other children, according to the theory of group adaptation, often determine low status of integrated child among other students, negative learning motyvation by disabled child.

Another one important feature of the integrated education - assessment of the student, which affects learning motivation. It is important to assess not the student, but his acting, achievements. A teacher should sometimes create situations of "success", that child could feel his own worth. For example: frontally working with the class, a teacher gives a question to a child with special needs, which coincides his abilities. Also, it's need to remember, that child can't be overrated - that makes a child to assess himself inadequately - for that reason needs to follow "the golden mean'. During education of children with special needs in general education school, a lot of discussions and obscurities are made by changing educational programs. Children with special needs can be taught by modified or adapted general education program, individual programs also are applied.

In Lithuania pedagogy of integration is only developing, it is based on individualized learning programs, child microlearning models in the environment of group - differentiated learning. However, searching for internal differentiation and individualization interfaces isn't sufficient. Often integrated education is based on general pedagogy concepts, which basis is children learning in homogeneous group. The conditions of different children participation in the educational precess, a variety of real situations, intersubjective interaction processes, reception of individual differences and conditions which can cause it are not sufficiently taken into account. Insufficiently is being highlighted the processes, which go together with children disability characteristics in integrated group, as a reception of individual differences. It is not shown how disabled children intercommunity with others is made, also, the pedagogical ways which help to maintain individual differences reception of children are not explored sufficiently. Thedemocratic European idea of integrated pedagogy, children's individual distinctiveness tolerance, disability characteristics reception processes in an integrated group in Lithuania is very important to accelerate full integration of disabled children in school, enabling them to learn in a group of healthy pupils (Juodaityte, 2000). 
A teacher working with a child must know according which program he needs to work, also it is very important to recognize the special needs of children as soon as possible and to provide appropriate assistance instead of abstract observations about child'sinaptitude. A teacher should pay attention if child has several problems, in this case, it's need to find the main problem, which is the most limiting education of a child, and give the maximum assistance for removal of difficulties in that field. However if student doesn't make any advance in particular sphere within the stipulated period, even if he gets assistance, it's worth to look for other, more effective ways to help. Usually, in this case teacher consults with school speech therapist or with special pedagogue.

The dynamic trivial round of society, increasing information flow, variety of ways to get information influence the changing of the school and every member of the school community. Lithuanian schools realizing the main goals of educational process, general programs and educational standardsrequirements, choosing teaching tools and educational methods are taking responsibility not only for quality of education, but also for continuous improvement of the process. School, as educational facilities providing institution, ensures equal educational opportunities for every child. Every year the organization of the educational process in general education schools is more complicated,needs greater flexibility and creativity. Children are coming to school with different life experience, raising in a bilingual environment, from a single parent family, growing in conditions of psychosocial deprivation, without learning motivation. Different language environment, differences in the sophistication of children, culture, healthy life skills determine that during the same time not all students are able to equally well obtain knowledge, abilities and skills, provided in General programs and educational standards.

Big demands have been made for pupils, because of that, they experience a lot of difficulties in order to justify their own, their parents and teachers expectations. More and more children with special needs are being teached in schools. These children have intellectual, specific cognition process, emotional disorders, as well as behavioral and social development, speech and communication, hearing, sight, movement and posture, chronic somatic and neurological complex disorders. After starting going to school, proceeding to higher learning level or new comers, some pupils adapt with difficulty. Gifted pupils learn among them and are superior than their coevals in development, thought and creativity. Formal education of children, which is based on traditional teaching methods won't create preconditions to overcome learning problems, academic backwardness. On the other hand, continual failures and stress will stop child's development. Only working together teachers, class masters, social pedagogue's, psichologist, speech therapist, care of society health specialist and parents can change this situation - working on time and single-mindedly will create conditions to evaluete child development's 
perculiarity and special needs. It would also help to render skilled assistence in order to meet special development requirements, ensure pupil's emotional, physical and social safety, successful integration into class and school's community.

Lithuanian school pursues the goal of each student's learning progress and a fullfledged socialization differentiating and individualizing the educational process. Every school tries to fullfil its tasks, the following:

- to get to know every student, taking his overall skills and values.

- to develop timely provided psychological, educational and social support system.

- to create a school climate satisfying individual security, emotional, physical and social needs.

- to help students successfully develop values, self-confidence, self-esteem and self expression.

All these raised common school goals and directions of support are also very important for children with special educational needs. The model diagram is shown in Picture 1.

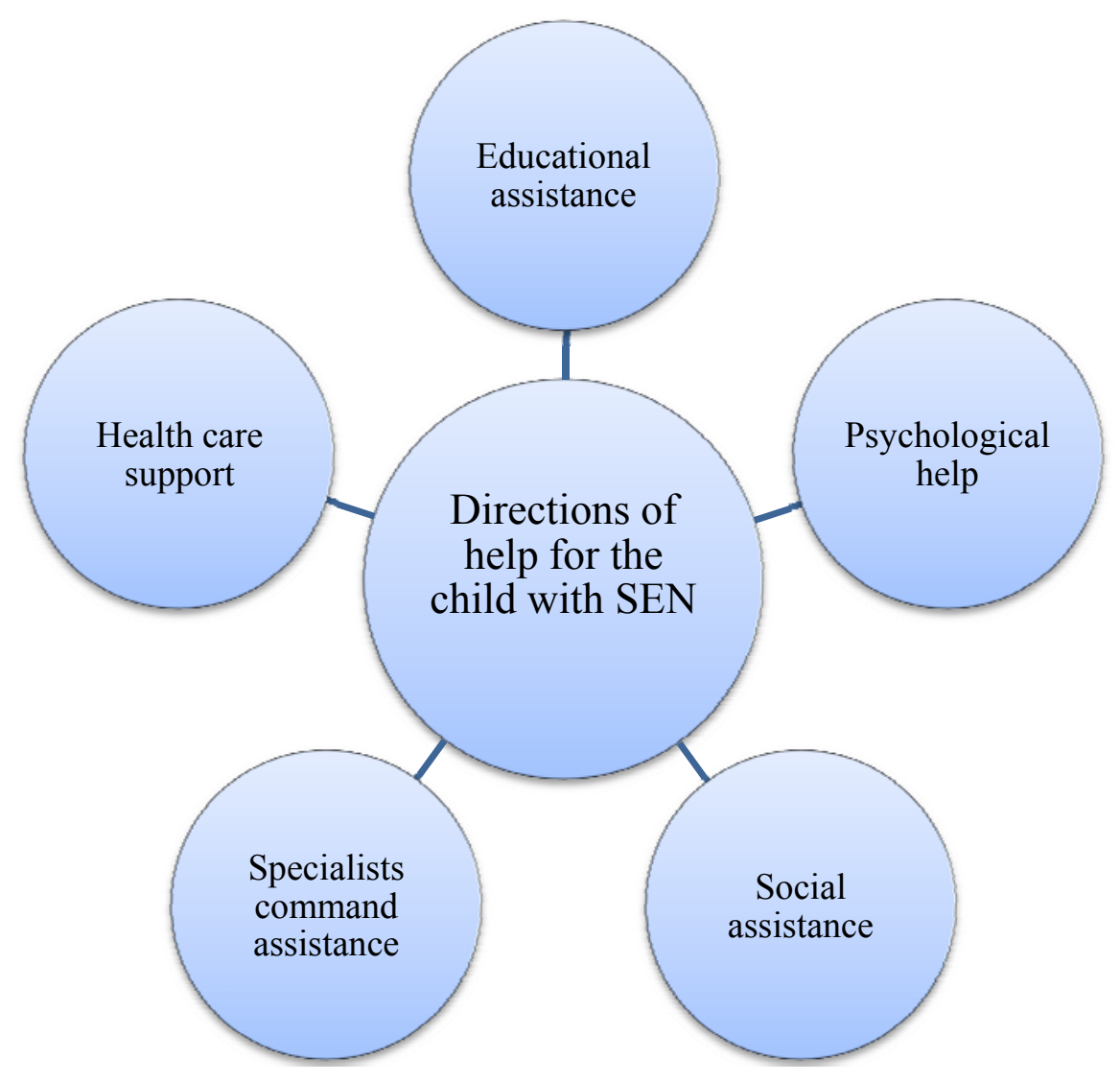

Fig.1 Directions of help for children with special needs

Department of Statistics materials show that between 2006 and 2011 the amount of the students with special needs decreased not as intensively as the total 
amount of the students. In 2006 the total amount of students were 535999 , meanwhile the total amount of the students with special needs were 51911 . In 2011, however, the total amount of the students decreased to 51306 , and the amount of the students with special needs dropped to 41 931. The downward dynamics of all students (picture 2). The main trend that emerges from the chart is that the number of children with special needs decreased slower than the total number of students.

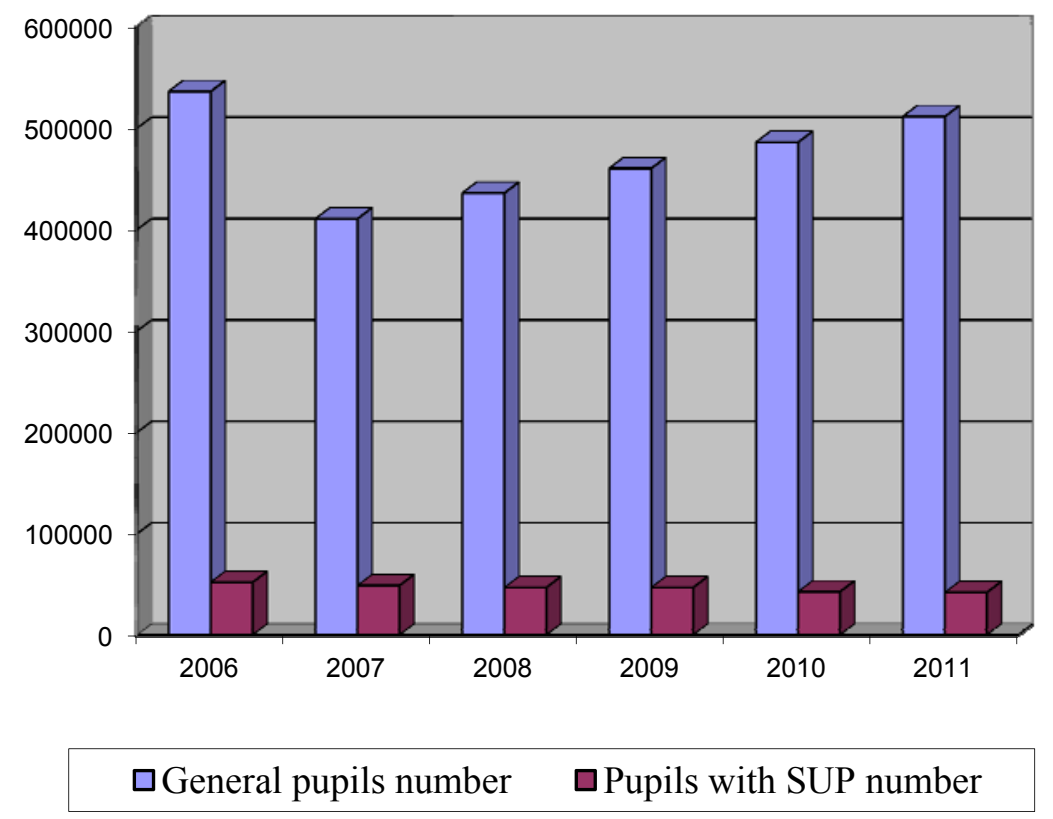

Fig. 2 Total number of pupils and number of pupils with special needs in 2006-2011

Analysing the data of the Departament of Statistics of 2006-2011 it was found that the number of children with special needs was decreasing slower than the total number of pupils in general schools. Though, one has to pay an attention to the fact that the comprehensive schools usually accept children with mild special needs, in $2006-74 \%$ while in 2011 - only $68 \%$. The percentage of integrated children with medium special needs in 2006 was $21 \%$, while in 2011 increased to $27 \%$. The number of children with substantial special needs in comprehensive schools grew very slowly, in 2006 it was 4\%, in 2011 increased to 5\%. In 2006 the percentage of children with very substantial special needs in schools was 1 $\%$, while in $2011-0 \%$ (according to the data of the Departament of Statistics). From this the inferences can be drawn, that though the number of children with mild special needs as well as the total number of pupils decreased, the schools began to accept the children with medium special needs who number in schools proportionally increased. In conclusion, the schools are ready to integrate the children with medium special needs, nevertheless, to answer the question if the needs of these children are respectively supplied is very difficult. It needs a specialresearch. 


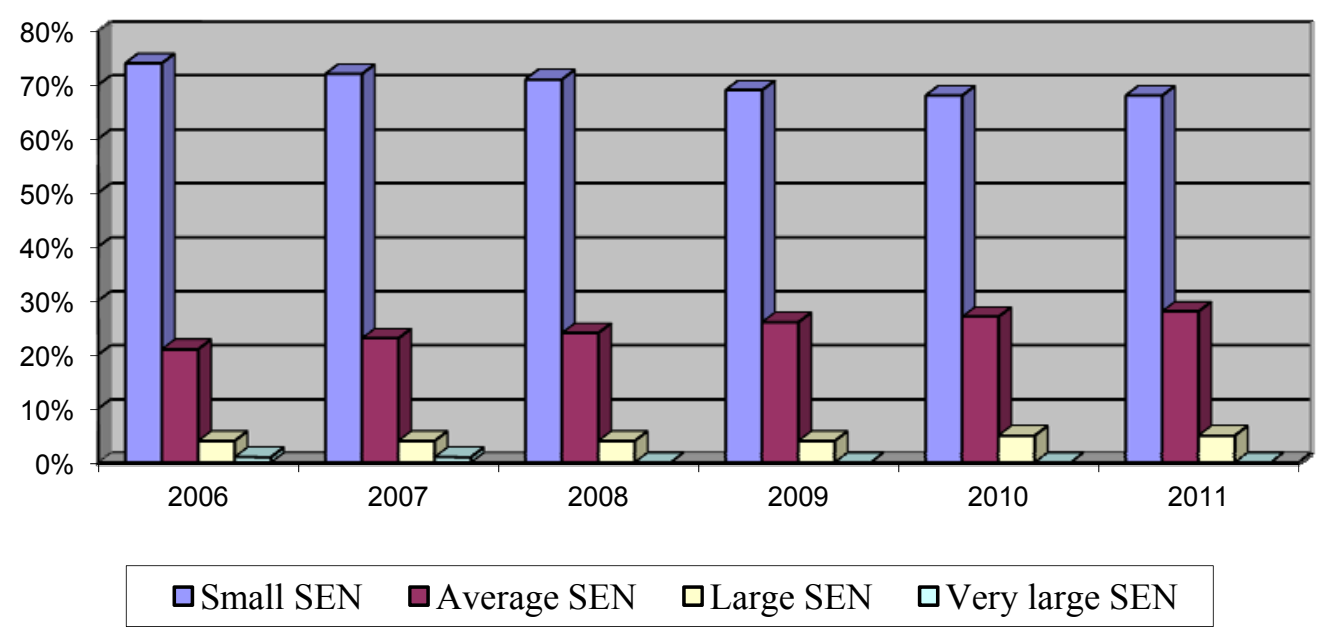

Fig. 3 Number of children with mild, medium, substantial and very substantial special needs integrated to general education institutions in 2006-2011

According to Ministry of Education and Science materials represented at the conference organized on June 19, 2012 in Vilnius we noticed that in rural areas were integrated $57 \%$ of children with special educational needs (what makes $6 \%$ of all students), and in the city $43 \%$ (what makes $5 \%$ of all students), it makes premises that, it can be presumed that in schools of rural areas is paid greater attention to children with special needs and these needs are better met. This statement requires a deeper investigation.

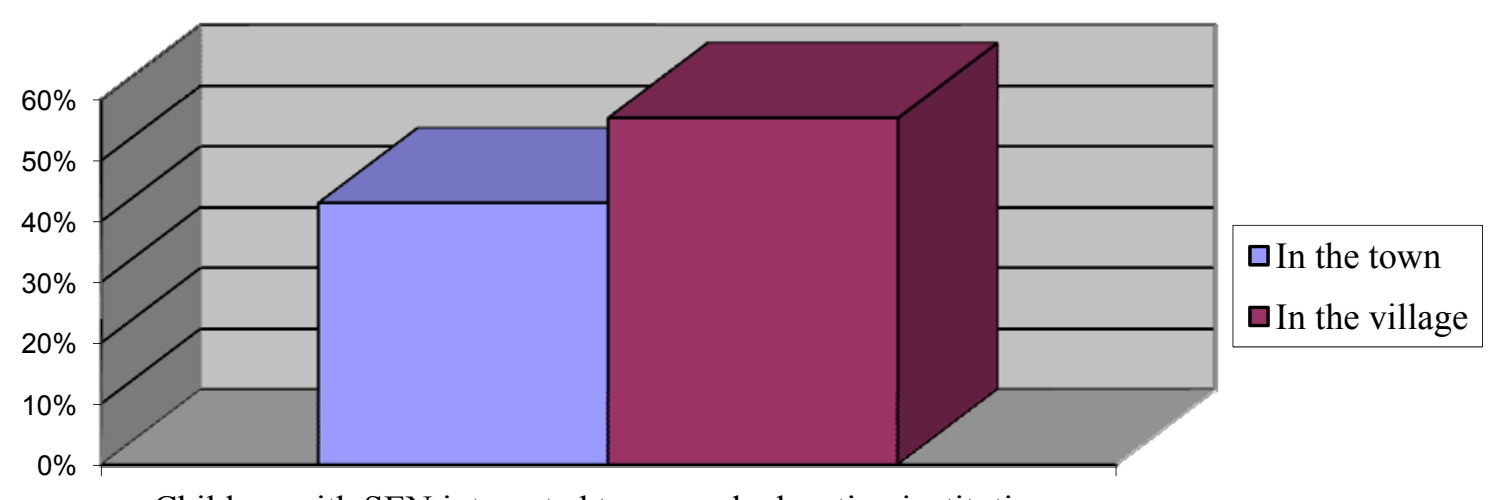

Children with SEN integrated to general education institutions

Fig.4 Children with SEN integrated to general education institutions 


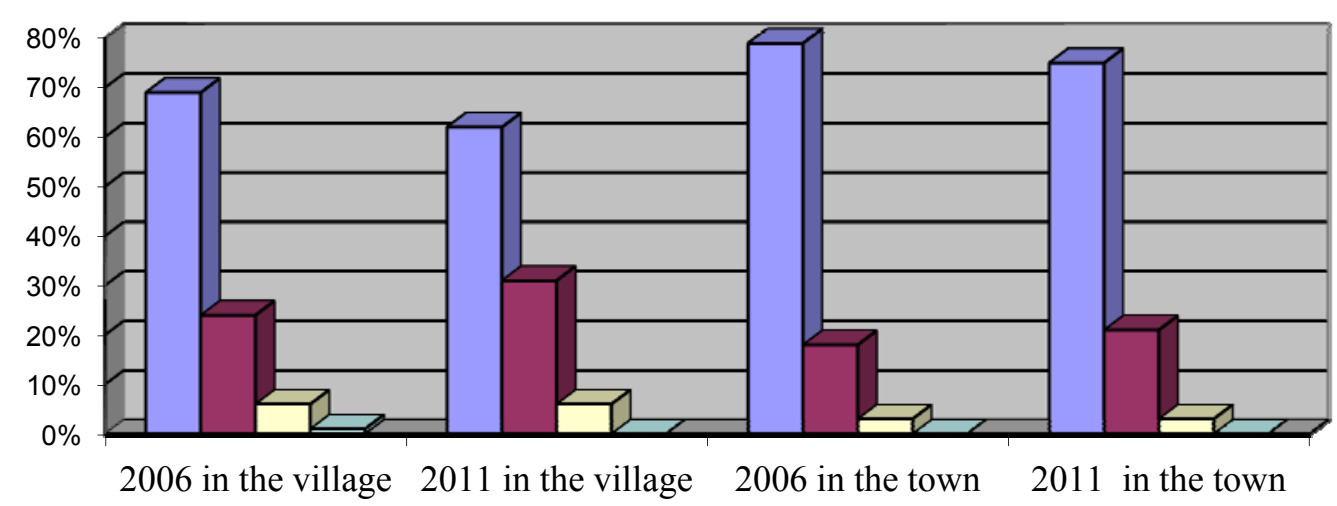

口Small SEN

$\square$ Average SEN

$\square$ Big SEN

$\square$ Very large SEN

Fig.5 Number of students with mild, medium, substantial and very substantial special needs integrated to general education institutions in urban and rural areas in 2006-2011

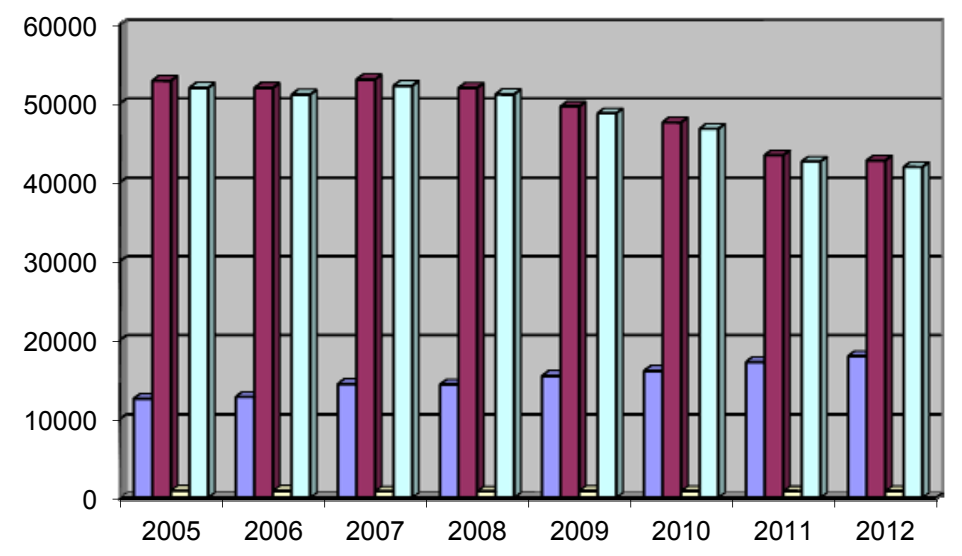

$\square$ Pre-school institutions of general education group

$\square$ General Education School

$\square$ Special, leveling and training classes (partial integration)

$\square$ General education class (complete integration)

Fig. 6 Children and studentswith special needs, integrated into educational institutions for the period 2005-2012

From Department of Statistics materials it can be noticed, thatin the year of 2003 into schools were integrated 54240 children with special educational needs, and in the year of 2012 in general education classes were left 41934 children with special educational needs. During 10 years the number of integrated children decreased12606 students. This downward trend of children in schools requires further and deeper research, that all reasons determined this trend could be found out. 


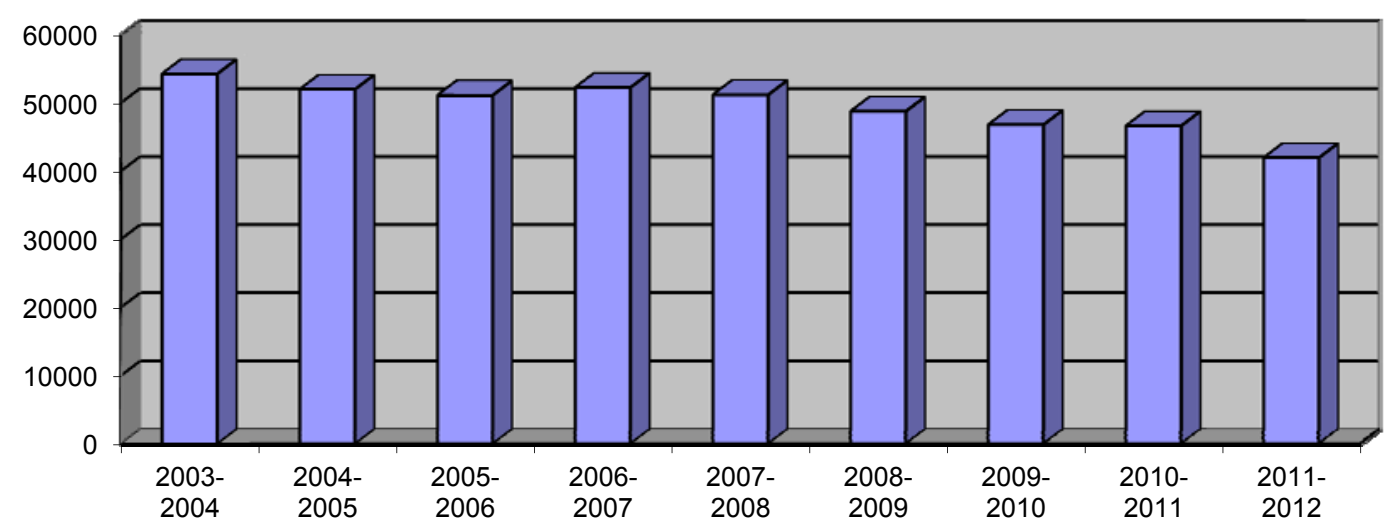

Fig. 7 Number of children with special needs integrated to general education classes in 2003-2012

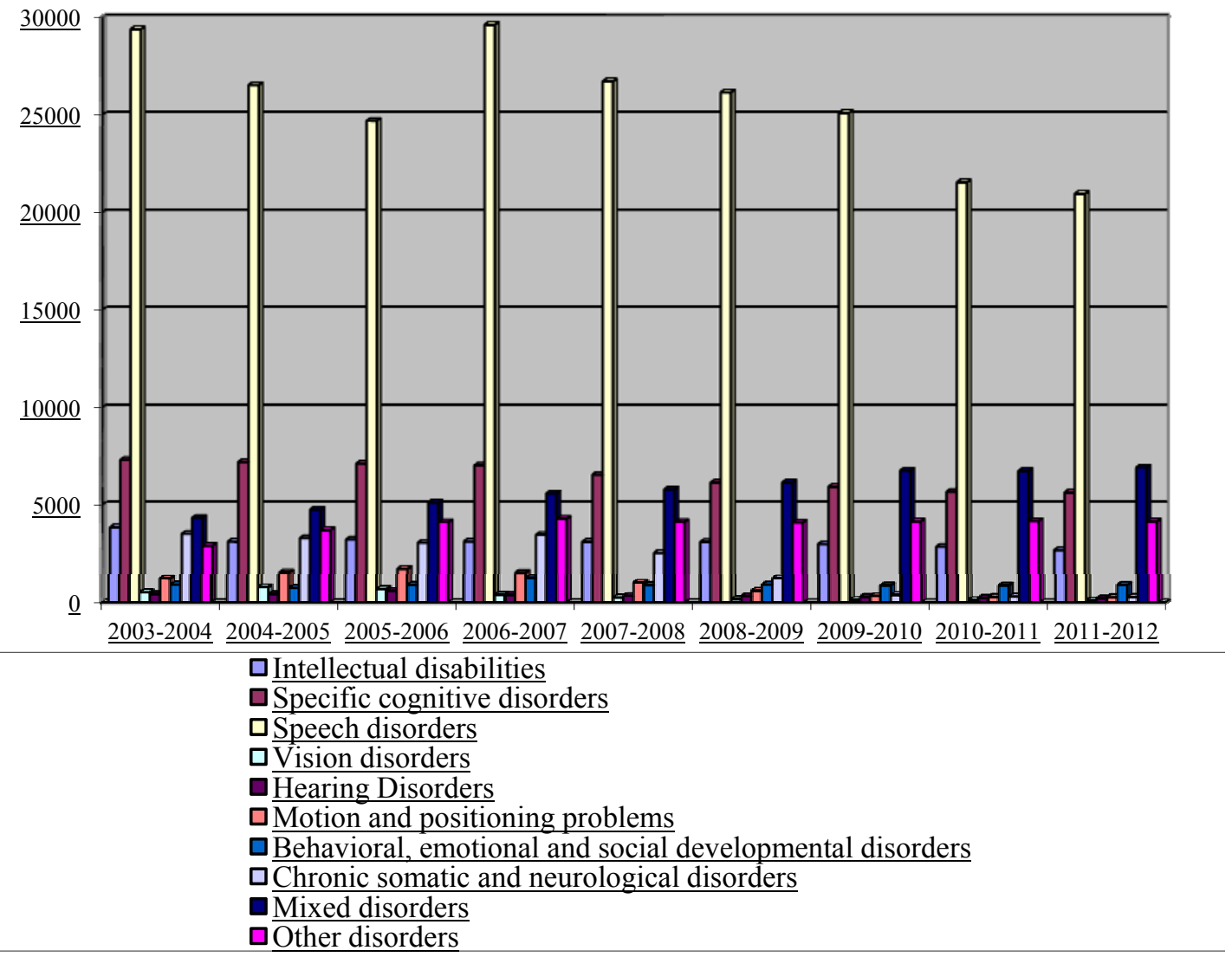

Fig. 8 Distribution of children with special needs integrated to general education institutions according to groups of disorders in 2003-2012

The examination of Department of Statistics materials about children with special needs integration into general education schools in 2003-2012 shows the same decreasing dynamics of children. However, it's neccessary to pay attention that in the picture for the most part are shown integrated children with language disorders. Knowing that most of schools have speech therapist, children may get special help. The number of children with motion and positioning problems 
from 1213 studentsin 2003has decreased to 248 studentsin 2012. The number of those with chronic somatic and neurological disordersfrom 3501 students in 2003 has decreased to 255 students in 2012.

The system of special education in Lithuania, like in any other country, is specific and determined by particular factors of history and culture, because different countries have a different experience in this field. The society's view to the children with special educational needs is being formed by country's traditions, philosophical attitudes, education and training policy. When country's education policy is being formed, it's very important to not forget to form a positive attitude about integration of disabled people and hold it by giving the same conditions of education to every child, considering to his capacities and abilities. In education is very important to trust yourself and others, being tolerant of each other. Special education is grounded by principles of general and special pedagogy. Such special schools apply all possible environmental and educational adaptation measures for these children: how is talking, how is acting, measures that are used. However, the most important pedagogical tools are relevant attitudes. This special school has abilities to provide students all the support and assistance which they need, but in the world outside of school everything is different, that's why children have to learn to adapt. All teachers of special school working with these children are special pedagogues.

Over the past decades both schools and individual teachers suggested integrated learning philosophy and it seems to be followed. It emphasizes respect for the individuality of each pupil, deviations are understoodas sources, not as problems. It corresponds to educational perspective by giving equal access to learn for every child.Education must always include the competence, selfconfidence and tolerance. In many schools and classes it is realized: every child can be noticed and appreciable. That disabled students would feel comfortable in general education schools among healthy students, there have to be positive microclimate in the class, appropriate teacher-student interaction, a common aim.

\section{Conclusions}

- From 2003 in Lithuania were implemented important educational reforms, which helped to integrate children with special needs into general education system, but this process varies bringing new tendences in integration. Despite the fact that process of integration in Lithuania is highly advanced and children with special needs are rapidly integrated into general education institutions, but special education institutions still are important part of the educational system. 
- It can be said that schools are not sufficiently prepared to integrate disabled child because of unequipped physical environment and lack of special and compensatory measures.

- Pedagogues working with children with special needs apply individual education programs, new educational methods, however, general education institutions have not enough special pedagogues, assistants, which could help disabled children during lessons.

\section{Summary}

The dynamics and inclusion forms of the integration of children with special educational needs to general educational institutions of Lithuania as well as the problems of integration of those children and perspectives of special education are analysed in the article. The integration often reaps various opinions and assessments,special education is often realized only like a formal transfer of children with special educational needs from one institution to another, without giving qualified assistance. The general education institutions are not always ready to accept those children. The integrated pedagogics in Lithuania is only at the initial stage and it is based on individualised teaching programms and it is based on individualized learning programs, child microlearning models in the environment of group - differentiated learning. The aim of this article is to analyse and describe theoretical background for inclusion of children with special educational needs to Lithuanian general educational system. Methods used in this research are scientific literature, statistics and rule of law analysis. The results have shown that educational reforms in Lithuania implemented since 2003 helped to integrate children with special needs to general education institutions while special education institutions remain the important part of the system. However, the general schools are not sufficiently prepared to integrate disabled children because of unuequipped physical enviroment, lack of compensatory measures, special pedagogues and teacher assistants.

\section{Literature}

1. Ališauskas, A. (2002). Vaiku ypatingumu ir specialiuju ugdymo(si) poreikiu ìvertinimas. Šiauliai: Šiaulių universitetas.

2. Ambrukaitis, J. (1998). Specialiu poreikiu vaikai. Šiauliai: Šiaulių universitetas.

3. Ambrukaitis, J. (2004) Specialiojo ugdymo pagrindai. Šiauliai: Šiaulių universitetas.

4. Bagdonas, A. (1995). Sutrikimu klasifikacija. Vilnius: Vilniaus universiteto leidykla.

5. Černius, V. (1997). Tévu ir mokytoju pagalbininkas. Kaunas.

6. Hallahan, P.D. Kauffman, M.J. (2003) Ypatingieji mokiniai. Specialiojo ugdymo ịvadas. Vilnius Alma littera.

7. Indrašienè, V. Mokymosi motyvacijos skatinimo galimybės / Mokinių pažangos ir pasiekimų vertinimo samprata. Švietimo naujienos. Informacinis leidinys. Nr. 5 (180) $2004 \mathrm{~m}$. kovas.

8. Lietuvos bendrojo lavinimo mokyklos bendrosios programos ir išsilavinimo standartai/ iterneti prieiga: http://www.smm.lt/ugdymas/docs/Programos2003.pdf 
9. Lietuvos Respublikos Švietimo ir mokslo ministro, Sveikatos apsaugos ministro ir Socialinès apsaugos ir darbo ministro įsakymas „Dèl specialiujų poreikių sutrikimų ir jų laipsnių nustatymo ir specialiujų poreikių asmenų priskyrimo specialiųjų ugdymosi poreikių grupei tvarkos $2002 \mathrm{~m}$. liepos $12 \mathrm{~d}$. Nr.1329/368/98; Iternetinè

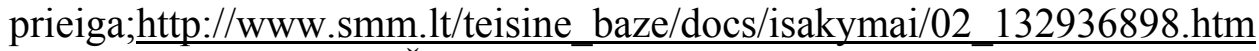

10. Lietuvos Respublikos Švietimo ir mokslo ministro issakymas „Dèl bendrujų socialinès pedagoginès pagalbos teikimo nuostatų patvirtinimo“ $2004 \mathrm{~m}$. birželio $15 \mathrm{~d}$. Nr. ISAK 941.htm. Internetinè prieiga: http://www.smm.lt/teisine baze/docs/isakymai/04-06-15ISAK-941.htm

11. Lietuvos Respublikos švietimo ir mokslo ministro įsakymas .Dèl psichologinès pagalbos teikimo tvarkos aprašo patvirtinimo. $2011 \mathrm{~m}$. liepos $5 \mathrm{~d}$. Nr. V-1215. Valstybès žinios, 2011-07-15 Nr.88-4220.

12. Petty, G. (2006). Šiuolaikinis mokymas. Praktinis vadovas. Vilnius: Tyto Alba.

13. Psichologijos žodynas. (2006). Vilnius: Mokslo ir enciklopedijų leidykla.

14. Reece, I. AndWalke, St. (1997). Teachinig, training and learning. A practical Guide. Great Britain.

15. Juodaitytè, A. (2001). Moderniosios vaiko ir vaikystės sampratos ir edukacinès idealogijos paieškos(prielaidos ir kryptys// Pedagogika Nr.41.

16. Juodaitytè, A. (2001). Konstuktyvizmas vaikystès pedagogų rengime// Pedagogika Nr.51.

17. Galkienè, A. (2005). Heterogetinių grupių dinamika:specialieji poreikiai bendrojo lavinimo mokykloje. Siauliai.

18. Gudonis, V. Novogrodskienè, E. (2003). Visuomenès požiūris ị neigaliuosius suaugusius ir specialiuju poriekių vaikus. Specialusis ugdymas III.

19. Ruškus, J. (2002). Negalès fenomenas: monografija. Šiauliai.

20. Rèklaitė D., Karpavičiūtė S., Požėrienė J. ,Kurčiųų ir neprigirdinčjiujų gyvenimo kokybės vertinimas. Specialusis ugdymas. 2010 Nr.1(22).

21. Kepalaitè, A. Socialinių pedagodų savirefleksijos ir ịžvalgos ypatumai. Specialusis ugdymas Nr. 1(22).

22. Geležinienè, $R$. Mokytojo veiklos konstravimas remiantis ịrodymais grịsta praktika. Specialusis ugdymas $2010 \mathrm{Nr}$. 1(22).

23. Miltenienè, L. Mauricienè, D. Komandinio darbo struktūra ir kryptingumas tenkinant specialiuosius ugdymo(si) poriekius mokykloje. Specialusis ugdymas $2010 \mathrm{Nr} .2(23)$.

24. Dizdarevič, A. Ibralič, F. Ugdymo programos pritaikymas individualiems mokinių, turinčių intelekto sutrikimą, poriekiams bendrojo lavinimo mokykloje. Specialusis ugdymas 2011. Nr. 1(24).

25. Mažeikaitè, N., Ruškè, J. Neịgaliųų orumo samprata ir ugdymas iš skirtingų teorinių perspektyvų: nuo esencializmo iki socialinio konstruktyvizmo. Specialusis ugdymas 2011 Nr.1(24).

26. Ališauskas, A., Kaffemanienè, I. Melienė, R. Miltenienè, L. Inkliuzinis ir specialusis ugdymas tèvų požiūrius. Specialusis ugdymas. 2011 Nr.2(25).

27. Ustilaitė,St., Kunigytė-Arlauskienè, I., Valančiūtė, L. Pedagogų nuostatos ị neịgaliujų vaikų integraciją bendrojo lavinimo mokyklose. Socialinis darbas. 2011-10(2).

28. Šinkariova, L., Baltutienè, A., Gudonis, V. Tèvų, auginančių vaikus, turinčius negalę, depresiškumo sąsajos su vaiko negalès ịpatumais. Specialusis ugdymas 2012 Nr.2 (27).

\begin{tabular}{|r|l|}
\hline Rita & M. Romeris university Social policy faculty \\
Virbaliene & Educology institute, Vilnius, Lithuania \\
& Email: rivirb@mruni.eu \\
& Tel. +37069904262
\end{tabular}

